\title{
Sciendo
}

PROCEEDINGS OF THE LATVIAN ACADEMY OF SCIENCES. Section B, Vol. 75 (2021), No. 1 (730), pp. 11-15.

\section{DETECTION AND GENOTYPING OF HUMAN PAPILLOMAVIRUS IN HYPOPHARYNGEAL CARCINOMA SAMPLES}

\author{
Andrejs Lifšics ${ }^{1, \#}$, Maksims Čistjakovs ${ }^{2}$, Valērija Groma ${ }^{3}$, and Modra Murovska ${ }^{2}$ \\ ${ }^{1}$ Department of Otorhinolaryngology, Rīga Stradinš University, 13 Pilsoṇu Str., Rīga, LV-1002, LATVIA \\ ${ }^{2}$ Institute of Microbiology and Virology, Rīga Stradiṇš University, 5 Rātsupītes Str., Rīga, LV-1067, LATVIA \\ ${ }^{3}$ Institute of Anatomy and Anthropology, Rīga Stradiňš University, 9 Kronvalda Blvd., Rīga, LV-1010, LATVIA \\ \# Corresponding author, andrejs.lifsics@gmail.com
}

Contributed by Modra Murovska

\begin{abstract}
The incidence of hypopharyngeal cancer globally is about 0.8 per 100000 . Globally, approximately 38000 cases of head and neck cancer are considered yearly to be high-risk human papillomavirus (HR-HPV) related. Biopsy material fixation in formalin and embedding in paraffin (FFPE) creates many challenges. The extraction of nucleic acid material requires a more complicated approach, and often the extracted DNA is fragmented. The aim of the study was to compare several HR-HPV detection methods in nucleic acid material extracted from FFPE samples. The extracted DNA was analysed with different molecular biology methods to assess DNA quality and to determine the presence of HPV DNA with various HPV detection systems. The results were compared and statistically analysed. There was good agreement between two real-time PCR methods - Anyplex II HPV28 and Sacace HPV High-Risk Screen Real-TM Quant. We failed to reach a conclusion on agreement between real-time PCR methods and HPV16 type-specific primer PCR. There was moderate positive correlation between Anyplex II HPV28 semiquantitative results and Sacace quantitative results. We suggest that real-time PCR assays detecting smaller DNA amplicons are good and reliable methods for detecting HPV genetic material in FFPE samples.
\end{abstract}

Key words: hypopharyngeal squamous cell carcinoma, FFPE, HPV.

\section{INTRODUCTION}

Worldwide there are approximately 600000 new cases of head and neck cancer registered yearly (Dayyani et al., 2010). That makes this region of the body to be the $6^{\text {th }}$ most common for cancer to appear in. The incidence of hypopharyngeal cancer is relatively low globally -0.8 per 100000 (1.4 in men and 0.3 in women) (Shield et al.,, 2017). Most head and neck cancers are squamous cell carcinomas (SCC).

In the last 20 years, the association between head and neck, especially, oropharyngeal squamous cell carcinoma and the presence of human papillomavirus (HPV) infection, has been established (Gillison et al., 2000; Gillison and Shah, 2001; Veyer et al., 2019). Globally, every year approximately 38000 cases of head and neck cancers are considered to be HPV-related (Plummer et al., 2016; de Martel et al., 2017). HPV16 and 18 have been generally recognised as the most frequent causative HPV types in head and neck cancer, particularly oropharyngeal SCC (Anonymous, 2007; Gillison et al., 2014; 2015; de Martel et al., 2017). There is still a pending question on the significance of the role of HPV infection in the development of hypopharyngeal and laryngeal SCC (Dahm et al., 2018). It was reported that about $5-7 \%$ of laryngeal cancers and as low as $0 \%$ of hypopharyngeal cancers were associated with high-risk (HR) HPV infection (Combes and Franceschi 2014; Plummer et al., 2016).

Of all head and neck SCC, hypopharyngeal manifests most aggressively. Conventionally, diagnosis is made based on histopathological examination of the tumour. Often, the amount of tissue is limited for extended examination, including for DNA and RNA extraction and testing. Even greater hurdles appear when biopsy material is formalin- 
fixed and embedded in paraffin (FFPE). Furthermore, DNA appears fragmented when applying a complicated approach for extracting nucleic acid material.

Fortunately, the development of FFPE DNA extraction kits has allowed the use of molecular biology methods for analysis of materials that have been stored for a long period and have small size.

Therefore, this study aimed to compare several methods of HR-HPV assessment in nucleic acid material extracted from hypopharyngeal SCC FFPE samples and to test different detection systems.

\section{MATERIALS AND METHODS}

Clinical material. We carried out a retrospective study of 31 patients diagnosed with hypopharyngeal SCC, staged following the TNM classification of the International Union against Cancer $\left(7^{\text {th }}\right.$ edition), and treated in Rìga East Clinical University Hospital, Stationary Oncology Centre of Latvia. The patients' data were collected from the Hospital Archive.

Collection of biopsy samples and tissue processing. Hypopharynx biopsy samples from patients hospitalised in Rīga East Clinical University Hospital, Oncology Centre of Latvia, were acquired between 2015 and 2019. All included patients belonged to a cohort declared and approved by Rīga Stradiňš University Ethics Committee (Decision No. 3/24.09.2015). The diagnosis of hypopharyngeal SCC was histopathologically confirmed. Biopsies were taken prior to treatment. Three to six $10 \mu \mathrm{m}$ thick sections cut from FFPE samples were used for DNA extraction. Each sample was sectioned separately with a clean blade to exclude crosscontamination of specimens.

DNA extraction. Thirty-one hypopharyngeal SCC FFPE samples were used for DNA extraction with a blackPREP FFPE DNA Kit (Analytik Jena, Germany) in accordance with the manufacturer's protocol.

The quality and quantity of DNA were estimated spectrometrically (Nanodrop ND-1000 Spectrophotometer, Thermo Fisher Scientific, Waltham, MA, USA). Beta- $(\beta-)$ globin PCR with appropriate primers was used to determine the quality of isolated DNA (Vandamme et al., 1995). Only $\beta$-globin positive samples were used for further analysis.

HPV DNA detection using MY09/11 and GP5+/6+ consensus primers. Polymerase chain reaction (PCR) with consensus primers MY9/MY11 and GP5+/6+ was used to detect the range of HR-HPV and low-risk HPV (LR-HPV) types (Shikova et al., 2009; Şahiner et al., 2014). The results were visualised by electrophoresis in $1.7 \%$ agarose gel. Amplification products of 450 base pairs (bp) and 150 bp length for MY09/11 and GP5+/6+ correspondingly were considered HPV positive. Positive and negative controls were included in each reaction.
Table 1. Primers used in the study

\begin{tabular}{l|l|c}
\hline \multicolumn{1}{c|}{ Primers } & \multicolumn{1}{c}{ Sequence $\left(5^{\prime}-3^{\prime}\right)$} & $\begin{array}{c}\text { Amplicon } \\
(\mathrm{bp})\end{array}$ \\
\hline $\begin{array}{l}\text { Consensus primers } \\
\text { MY09 }\end{array}$ & CGTCC(AC)A(AG)(AG)GGA(T)ACTGATC & \multirow{2}{*}{450} \\
MY11 & GC(AC)CAGGG(AT)CATAA(CT)AATGG & \\
GP5+ & TTTGTTACTGTGGTAGATACTAC & 150 \\
GP6+ & GAAAAATAAACTGTAAATCATATTC & \\
Type-specific primers & 152 \\
$16 . L 1-1$ & TGCTAGTGCTTATGCAGCAA & \\
$16 . L 1-2$ & ATTTACTGCAACATTGGTAC & 216 \\
18.1 & AAGGATGCTGCACCGGCTGA & \\
18.2 & CACGCACACGCTTGGCAGGT &
\end{tabular}

HPV genotyping using isolated HPV16 and HPV18 primers. The primers used to detect HPV16 and HPV18 specific genomic sequences are summarised in Table 1 (Shikova et al., 2009). Amplification using HPV16 specific primers produces 152 bp long amplicons and using HPV18 specific primers - $216 \mathrm{bp}$ amplicons. The results were visualised by electrophoresis in $1.7 \%$ agarose gel. Reactions were performed with the use of positive and negative controls. Positive and negative controls were included in each reaction.

HPV detection and genotyping by Anyplex II HPV28. Anyplex II HPV28 multiplex real-time PCR (RT-PCR) was performed as recommended by the manufacturer (Seegene, South Korea). A specimen of $5 \mu \mathrm{l}$ DNA was added in each of two sets (wells) with $20-\mu$ PCR reaction mix. Set A consisted of primer mix for 14 HR-HPV types (HPV16, 18, 31, $33,35,39,45,51,52,56,58,59,66$, and 68), and set B consisted of primer mix for five possible HR-HPV types (HPV26, 53, 69, 73, and 82) and nine LR- HPV types (HPV6, 11, 40, 42, 43, 44, 54, 61, and 70). Both primer sets were designed for the HPV L1 gene and produced 100 and 200 bp long amplicons, respectively.

Melting curves were obtained at 30, 40, and 50 cycles allowing semiquantitative specimen analysis and differentiating between high $(+++)$, medium $(++)$, or low $(+)$ viral loads, and there were internal positive and negative controls. The kit had DNA quality control by detecting the $\beta$-globin gene. The results were analysed using the Seegene Viewer software (Seegene).

HPV detection by Sacace HPV High-Risk Screen RealTM Quant. HPV High-Risk Screen Real-TM Quant (Sacace Biotechnologies, Italy) is an in vitro real-time amplification test for quantitative detection of HPV types 16, $18,31,33,35,39,45,51,52,56,58,59$. It includes mixture of primer for HPV groups A7, A9 (HPV16, 18, 31, 33, 35, 39, 45, 52, 58, 59), HPV group A5 (HPV51), and HPV group A6 (HPV56), and has an internal control ( $\beta$-globin gene). The kit contains quantitative standards with the known concentration of HPV DNA, used for calculation of the viral load. 
Statistical data analysis. Seegene results were assessed semiquantitatively and coded as follows: 1 - negative; 2 for $+; 3-$ for ++ ; and $4-$ for +++ . Viral load (copies $/ 10^{5}$ cells) from the Sacace assay was expressed in $\log _{10}$ and submitted to statistical analysis. For negative samples, $\log _{10}$ random values of 0 (viral load of approximately 1 copies $/ 10^{5}$ cells) as a mean and SD of 0.1 were assigned (generated with GraphPad Prism random number generator).

Cohen's $\kappa$ test was used to assess agreement between the HPV detection methods with 1 - indicating perfect agreement; 1 to 0.81 - very good agreement; 0.80 to $0.61-$ good agreement; and 0.60 to 0.21 - moderate to a poor agreement.

The Mann-Whitney test was used to assess if the differences of nonparametric data were significant. Relations between viral load (Sacace assay) and semiquantitative results (Anyplex assay) were investigated using nonparametric Spearman's correlation analysis (Mukaka, 2012; Akoglu, 2018).

A nonlinear regression model was used to graphically assess the relationship between the viral load and the semiquantitative results of Anyplex II HPV28 assay.

\section{RESULTS}

Thirty-one patients with hypopharyngeal SCC were included in this study. Most patients were male $(93.5 \%, \mathrm{n}=$ $29)$, with only two female patients $(6.5 \%)$. The mean patient age was 66.3 years (range 44-83.3), median - 65.2 years. Unfortunately, all of the patients presented with advanced disease stage $-11(35.5 \%)$ with stage III, and $20(64.5 \%)$ — with stage IV.

DNA extraction from FFPE samples was an easy and not time-consuming procedure when using the blackPREP FFPE DNA Kit. The lowest extracted DNA concentration was $16.54 \mathrm{ng} / \mu \mathrm{l}$; in most of the extracted DNA samples the concentration was above $60 \mathrm{ng} / \mu \mathrm{l}$. All extracted DNA samples were $\beta$-globin gene-positive, which made them viable for further analysis.

Of the 31 hypopharyngeal SCC FFPE samples, only 1 was positive for HPV using MY09/11 consensus primers. In contrast, GP5+/6+ consensus primers were much more efficient with positivity of $100 \%(\mathrm{n}=31)$ for HPV DNA.

Further HPV genotyping using HPV16 and HPV18 specific primers showed positivity for HPV16 only. Of 31 samples, $15(48.4 \%)$ were positive for HPV16.

Anyplex II HPV28 assay showed HPV positivity for 14 (45.2\%) samples. In one case, there was co-infection by 2 HPV types (type 16 and 56), with the remaining 13 cases positive for HPV16.

The Sacace HPV High-Risk Screen Real-TM Quant test showed HPV positivity for $12(38.7 \%)$ samples in HEX channel, which corresponded to the HPV A9 group (16, 31, $33,35,52,58)$.

Comparison of HPV detection and genotyping results between HPV16 specific primers, Anyplex II HPV28 assay, and Sacace HPV High-Risk Screen Real-TM Quant. The same DNA extracts from the 31 selected FFPE samples tested by GP5+/6+ and HPV16 specific primers, were further subjected to Anyplex II HPV28 assay, and Sacace HPV High-Risk Screen Real-TM Quant assay. Valid results with the use of both assays were obtained for all 31 biopsy samples.

Although, HPV16 specific primers' PCR and Anyplex assay showed similar positivity in overall count sense (15/14 positive out of 31), only 9 cases were identical. The remaining positive cases were discordant, meaning cases positive in PCR with HPV16 specific primers were negative in Anyplex II HPV28 assay, and vice versa. We could not assess the agreement of both tests because of the high $p$-value of Cohen's kappa (Cohen's $\kappa$ coefficient $=0.288, p=$ 0.156). Comparison of the results from PCR with HPV16 specific primers and Sacace assay showed a similar result (Cohen's $\kappa$ coefficient $=0.285, p=0.149$ ), meaning that the agreement between these two methods could not be assessed with significance.

Among the 14 HPV-positive samples by Anyplex assay, 11 (78.6\%) were found positive by the Sacace assay. Simultaneously, three samples positive in Anyplex assay were negative in Sacace assay. One sample was positive in the Sacace assay while negative in the Anyplex assay. The agreement between both methods was good (Cohen's $\kappa$ coefficient $=0.736, p<0.001)$

HPV viral load. As previously mentioned, HPV High-Risk Screen Real-TM Quant (Sacace Biotechnologies, Italy) is an in vitro real-time amplification test for quantitative detection of HPV. Although it does not specifically show the type of HPV, it has three channels for different types of HPV. The analysed samples showed positive signals in the HEX channel only, which corresponded to HPV16.

There was a moderate positive correlation between viral load (assessed by Sacace assay) and semiquantitative Seegene assay results estimated semiquantitatively (Spearman's correlation coefficient $=0.60$, CI $0.30-0.79, p=0.0004$ ), Figure 1.

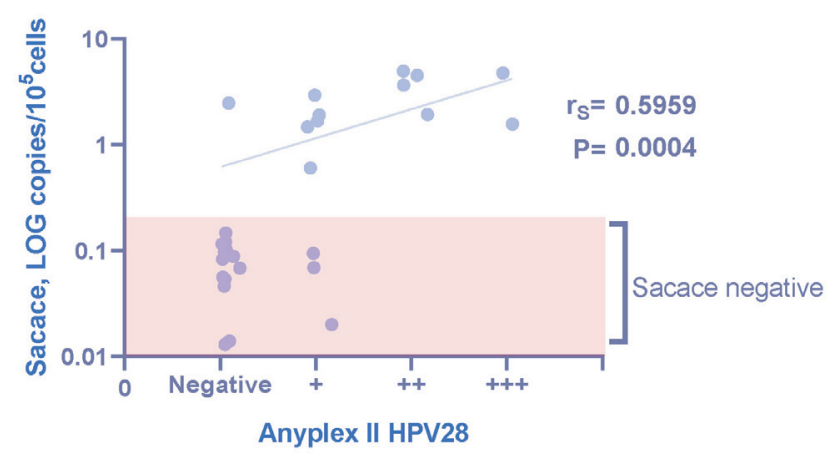

Fig. 1. Correlation between two RT-PCR assays. 


\section{DISCUSSION}

All methods were used on the same DNA extracts, which makes the results highly accurate and applicable for assessment of agreement between different HPV detection methods.

As shown in different studies, the Anyplex II HPV28 assay is an appropriate and dependable HPV detection method with good sensitivity and specificity (Cornall et al., 2017; Del Pino et al., 2017; Baasland et al., 2019; Veyer et al., 2019). However, there has been data acknowledging the need for additional conformational HPV16 genotype-specific molecular assay, especially for HPV-negative samples (Veyer et al., 2019). In our study we were unable to surely conclude agreement/disagreement between Anyplex II assay and HPV16-specific primer PCR results. Simultaneously, we had multiple HPV16 positive samples by HPV16 specific primers' PCR, diagnosed as negative in Anyplex II HPV28 assay and vice versa. This suggests the need for multiple detection methods for FFPE DNA extracts.

Previous studies have demonstrated that genetic material extracted from FFPE is highly variable in terms of DNA quality and quantity (Lillsunde Larsson et al., 2015). Various factors can affect the results of assessment - reagents used in a fixation procedure, the amount of tissue submitted to fixation and further tissue processing, etc. (Srinivasan et al., 2002; Ludyga et al., 2012). This applies even more for hypopharyngeal biopsy material, as biopsies are performed using local anesthetic with indirect visualisation. Nevertheless, our results show that even small amounts of DNA concentration can be successfully used for HPV DNA detection.

MY09/11 consensus primers produce 450 bp long amplicons. In our study, we had only one (of a total of 31) HPV-positive specimens with the use of these primers. In contrast, GP5+/6+ primers produce 150 bp long amplicons, which resulted in $100 \%$ positivity in our study. Therefore, we suggest that primers for shorter HPV DNA amplicons are more beneficial, especially in fragmented DNA extracted from FFPE samples.

Our observations demonstrate that Anyplex II HPV28 and Sacace HPV High-Risk Screen Real-TM Quant assays can be used in a clinical laboratory to detect and genotype HPV in FFPE samples. The combination of these two assays has a beneficial effect when detecting different HPV types and estimating the viral load.

In conclusion, it seems that RT-PCR assays detecting smaller DNA amplicons are good and reliable for detecting HPV genetic material in FFPE samples. However, confirmation of HPV detected using additional HPV methods may be applicable when searching for overall sensitivity.

The author declares that there is no conflict of interest.

\section{ACKNOWLEDGMENTS}

R̄̄ga Stradiň̌̌ University Department of Doctoral Studies is acknowledged for reagents and publishing support.

\section{REFERENCES}

Akoglu, H. (2018). User's guide to correlation coefficients. Turkish J. Emerg. Med., 18, 91-93.

Anonymous (2007). IARC Monographs on the Evaluation of Carcinogenic Risks to Humans. Vol. 90. Human Papillomaviruses. International Agency for Research on Cancer, Lyon. 689 pp.

Baasland, I., Romundstad, P. R., Eide, M. L., Jonassen, C. M. (2019). Clinical performance of Anyplex II HPV28 by human papillomavirus type and viral load in a referral population. PLOS ONE, 14 (1), e0210997.

Combes, J.-D., Franceschi, S. (2014). Role of human papillomavirus in non-oropharyngeal head and neck cancers. Oral Oncol., 50, 370-379.

Cornall, A. M., Poljak, M., Garland, S. M., Phillips, S., Machalek, D. A., Tan, J. H., Quinn, M. A., Tabrizi, S. N. (2017). HPV genotype-specific concordance between EuroArray HPV, Anyplex II HPV28 and Linear Array HPV Genotyping test in Australian cervical samples. Papillomavirus Res., 4, 79-84.

Dahm, V., Haitel, A., Kaider, A., Stanisz, I., Beer, A., Lill, C. (2018). Cancer stage and pack-years, but not p16 or HPV, are relevant for survival in hypopharyngeal and laryngeal squamous cell carcinomas. Eur. Arch. Oto-Rhino-Laryngol., 275, 1837-1843.

Dayyani, F., Etzel, C.J., Liu, M., Ho, C.-H., Lippman, S. M., Tsao, A. S. (2010). Meta-analysis of the impact of human papillomavirus (HPV) on cancer risk and overall survival in head and neck squamous cell carcinomas (HNSCC). Head Neck Oncol., 2, 15.

Del Pino, M., Alonso, I., Rodriguez-Trujillo, A., Bernal, S., Geraets, D., Guimera, N., Torne, A., Ordi, J. (2017). Comparison of the analytical and clinical performance of five tests for the detection of human papillomavirus genital infection. J. Virol. Meth., 248, 238-243.

Gillison, M. L., Castellsagué, X., Chaturvedi, A., Goodman, M. T., Snijders, P., Tommasino, M., Arbyn, M., Franceschi, S. (2014). Eurogin Roadmap: Comparative epidemiology of HPV infection and associated cancers of the head and neck and cervix. Int. J. Cancer, 134, 497-507.

Gillison, M. L., Chaturvedi, A. K., Anderson, W. F., Fakhry, C. (2015). Epidemiology of human papillomavirus-positive head and neck squamous cell carcinoma. J. Clin. Oncol., 33, 3235-3242.

Gillison, M. L., Koch, W. M., Capone, R. B., Spafford, M., Westra, W. H., Wu, L., Zahurak, M. L., Daniel, R. W., Viglione, M., Symer, D. E., Shah, K. V., Sidransky, D. (2000). Evidence for a causal association between human papillomavirus and a subset of head and neck cancers. J. Natl. Cancer Inst., 92, 709-720.

Gillison, M. L., Shah, K. V. (2001). Human papillomavirus-associated head and neck squamous cell carcinoma: Mounting evidence for an etiologic role for human papillomavirus in a subset of head and neck cancers. Curr. Opin. Oncol., 13, 183-188.

Lillsunde Larsson, G., Carlsson, J., Karlsson, M. G., Helenius, G. (2015). Evaluation of HPV genotyping assays for archival clinical aamples. J. Mol. Diagn., 17, 293-301.

Ludyga, N., Grünwald, B., Azimzadeh, O., Englert, S., Höfler, H., Tapio, S., Aubele, M. (2012). Nucleic acids from long-term preserved FFPE tissues are suitable for downstream analyses. Virchows Archiv., 460, 131-140.

de Martel, C., Plummer, M., Vignat, J., Franceschi, S. (2017). Worldwide burden of cancer attributable to HPV by site, country and HPV type. Int. J. Cancer, 141, 664-670.

Mukaka, M. (2012). A guide to appropriate use of correlation coefficient in medical research. Malawi Med. J., 24, 69-71. 
Plummer, M., de Martel, C., Vignat, J., Ferlay, J., Bray, F., Franceschi, S. (2016). Global burden of cancers attributable to infections in 2012: A synthetic analysis. The Lancet. Global Health, 4, e609-616.

Şahiner, F., Kubar, A., Gümral, R., Ardıç, M., Yiğit, N., Şener, K., Dede, M., Yapar, M. (2014). Efficiency of MY09/11 consensus PCR in the detection of multiple HPV infections. Diagn. Microbiol. Infect. Dis., 80, 43-49.

Shield, K. D., Ferlay, J., Jemal, A., Sankaranarayanan, R., Chaturvedi, A. K., Bray, F., Soerjomataram, I. (2017). The global incidence of lip, oral cavity, and pharyngeal cancers by subsite in 2012. Cancer J. Clin., 67, 51-64.

Shikova, E., Todorova, I., Ganchev, G., Kouseva-Dragneva, V. (2009). Detection and typing of human papillomaviruses by PCR. Biotechnol. Biotechnol. Equip., 23, 877-880.
Srinivasan, M., Sedmak, D., Jewell, S. (2002). Effect of fixatives and tissue processing on the content and integrity of nucleic acids. Amer. J. Pathol., 161, 1961-1971.

Vandamme, A.-M., Fransen, K., Debaisieux, L., Marissens, D., Sprecher, S., Vaira, D., Vandenbroucke, A. T., Verhofstede, C., Van Dooren, S., Goubau, P. et al. (1995). Standardisation of primers and an algorithm for HIV-1 diagnostic PCR evaluated in patients harbouring strains of diverse geographical origin. J. Virol. Meth., 51, 305-316.

Veyer, D., Wack, M., Grard, O., Bonfils, P., Hans, S., Belec, L., Badoual, C., Péré, H. (2019). HPV detection and genotyping of FFPE head and neck cancer biopsies by molecular testing to address new oropharyngeal squamous cell carcinoma classification based on HPV status. Pathology, 51 (4), 421-425.

Received 17 July 2020

Accepted in the final form 21 November 2020

\section{CILVĒKA PAPILOMAS VĪRUSA (CPV) NOTEIKŠANA UN TIPĒŠANA HYPOPHARYNX PLAKANŠUNU KARCINOMAS PARAUGOS}

Hypopharynx vēža ikgadēja pasaules incidence ir aptuveni 0,8 uz 100 000. Tiek uzskatīts, ka aptuveni 38000 galvas un kakla vēža gadījumu ir CPV infekcijas izraisīiti. Ir daudz grūtību, kas saistītas ar biopsijas materiāla, kas fiksēts formalīnā un ieguldīts parafīnā, molekulāri bioloǵisko analīzi. DNS izdalīšana no šādiem paraugiem bieži vien ir laikietilpīga, grūtāka, un izdalītā DNS nereti ir fragmentēta. Šì pêtījuma mērkis bija salīdzināt vairākas augsta riska CPV noteikšanas metodes no parafīna blokiem izdalītajā ğenētiskajā materiālā. Tika noteikta izdalītās DNS kvalitāte, kā arī CPV DNS klātbūtne, izmantojot vairākas CPV noteikšanas "sistēmas". Rezultāti tika salīdzināti un statistiski analizēti. Starp divām reālā laika polimerāzes ḳēdes reakcijas (PḲR) metodēm (Anyplex II HPV28 un Sacace HPV High-Risk Screen Real-TM Quant) bija vērojama laba sakritība. Mēs nevarējām izdarīt statistiski ticamus secinājumus par rezultātu sakritību starp reālā laika PĶR metodēm un HPV16 specifisko praimeru PḲR. Daudziem paraugiem bija ne tikai identiski, bet arī pretēji rezultāti šo metožu lietojumā. Starp Anyplex II HPV28 puskvantitatīvajiem rezultātiem un Sacace kvantitatīvajiem rezultātiem bija mērena pozitīva korelācija. Secinājums: reālā laika PCR testi, ar kuru palīdzību var noteikt mazākus DNS amplikonus, ir labas un uzticamas metodes CPV ǵenētiskā materiāla noteikšanai parafīna bloku paraugos. 